Radoje Jevtić, $\mathrm{PhD}^{1}$

Electrotechnical school Nikola Tesla, Niš

UDK - 614.841.45 + 004.383.4

Примљено: 19.02.2015.

\title{
SELECTION OF THE FIRE DETECTORS AND THEIR ARRANGEMENT IN OBJECT ${ }^{2}$
}

\begin{abstract}
The appearance of fire in objects, especially in objects with lot of humans inside represents very possible real situation that could be very danger and could cause destructive consequences on human lives and material properties. Very important task in fire protection, human and material properties safety could be a proper adoption of fire detectors and theirs disposition in object. The right type of fire detectors, with theirs disposition and density has to provide right time reaction, with minimal occurrence of false alarms and acceptable price. There are many different factors for fire detectors selection. On the other hand, there are several standards for fire detectors disposition. This facts show that good projected fire protection system must satisfied a lot of different and important tasks. This paper presents representation of fire detectors, their selection according to the different factors, theirs disposition in object according to proper standards and simulation in PyroSim software as an evidence for noted facts.
\end{abstract}

Key words: fire, detector, simulation, objekt

\section{INTRODUCTION}

The fire presents one of the biggest problems of present modern life. Generally, the fire presents uncontrolled and unpredictable process of heat propagation. Although there are many modern regulative, standards, equipment for fire protection, each year there are many human victims and material disaster that present consequences of fire. One of the most important fire parameter is combustion. It presents the series of the chemical reactions be-

\footnotetext{
${ }^{1}$ E-mail: milan.jvtc@gmail.com

${ }^{2}$ The paper presents a small part of large research applied for realization of PhD thesis "Fire and burglary protection using non-typical electric lines", which was approved by University of Niš, evidence number 8/20-01-003/11-019, defended on 19.06.2014 at the University of Niš- Faculty of occupational safety.
} 
tween the fire material and oxygen, where the releasing of the heat, smoke and flame are present. To reach the combustion process, the presence of all noted components is required: fire material, heat source and oxygen, which means that the lack of any of noted components stops the combustion process. If the combustion process comes without influence of the external source, it will be defined as self trigger process. The combustion process consequence is the heat transfer. Considering the fire detection, it is very important fact that the heat, as the measure of the warming, presents the only parameter that could produce the signal which is not need to amplify. There were three basic mechanisms of the heat transfer: conduction, convection and radiation. These mechanisms are presented on figure 1 .

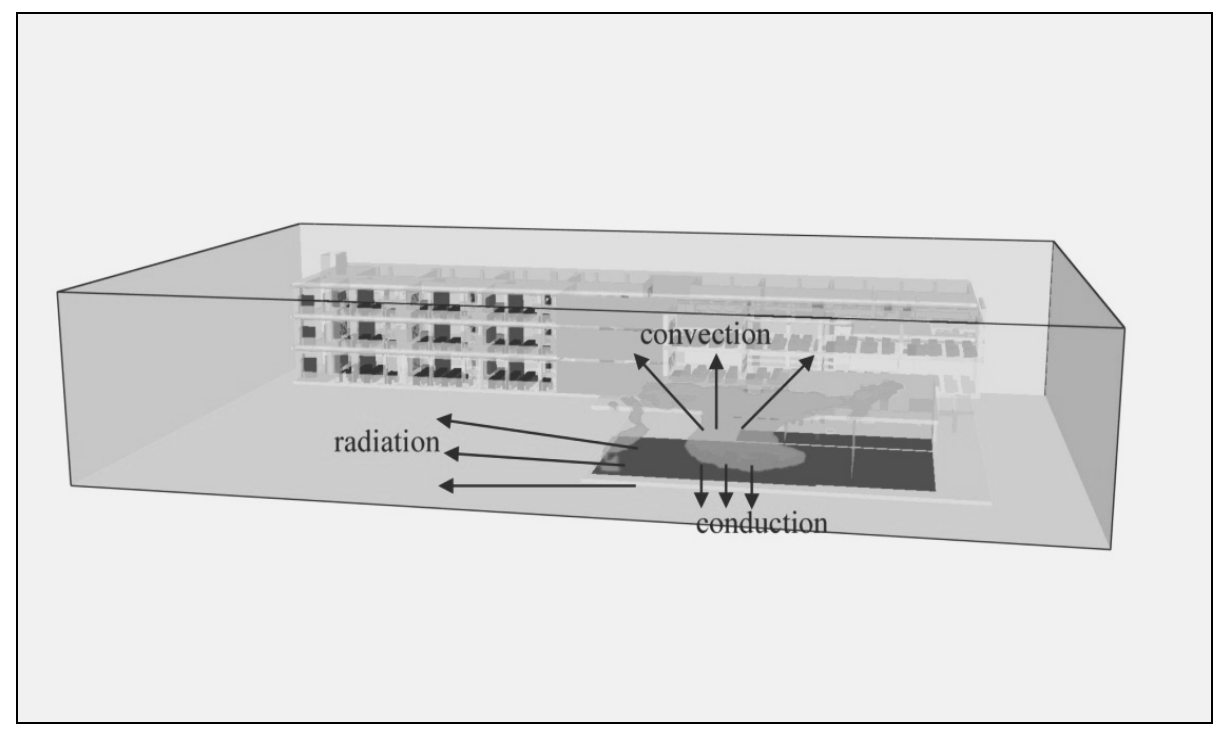

Figure 1. Three basic mechanisms of heat transfer

(Source: Jevtić, 2013)

The fire is characterized with big number of parameters. These parameters characterize burning zone, heat effect zone and smoke zone. From detection aspect, material and energetic converts are very important because their products present fire dimensions that could be used for success and precise fire detection. The development time and combustion products that were made in fire present the base for fire detection and information.

Nowadays level of fire protection implies the projection of complete fire system based on valued standards. It is very complex process, because, beside many start bases of projection which were predicted by law standards, regulation and references, it includes many factors which were attained according to the fire risk analyze, characteristics of the object construction, 
characteristics of the activities and production process in object, materials and stuff in object, working and professional characteristic of personnel, etc. The last of the quality tasks in alarm system realization, generally, was the computer introduction as the highest hierarchy level in the system and central place for signalization, supervision and management. On that way, with the usage of computer data processing and possibilities for Internet and other nets accessing, the efficiency of fire protection systems was multiple increased (Furness, Mucket, 2007).

The base purpose of fire protection systems is to provide information to the user about fire genesis in order to avoid human victims and material damage. For that reason, fire protection system consists of many different parts connected in one unique system. Precision and correct work of every part of fire protection system has crucial importance. Detectors present one of the main elements of all real time systems that collect data measuring material and energetic changes of supervised occurrence.

Generally, detector implies three parts: sensor part (reacts on supervised parameters change), converter part (converts data from sensor into electrical dimension) and part for signal conditioning (realizes amplification, filtration and normalization of signal gained from sensor). The fire detectors could be classified on different ways and according to different criteria (for example, according to the combustion product types, according to the detector effective zone, according to the detector activation mode etc.). One of those classifications is presented on figure 2 (Blagojević, 2011:37), (Jevtić, 2014b), (Živanović, 2010).

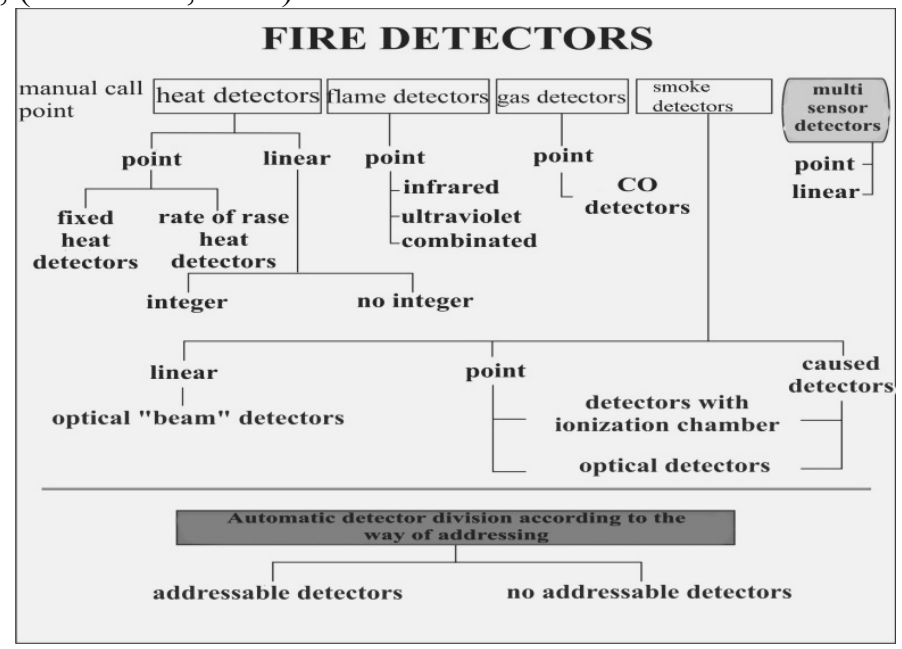

Figure 2. Fire detectors division

(Source: Blagojević, 2011) 


\section{THE FIRE DETECTORS SELECTION}

The standards of the most develop countries contain parts according to the sensibility prediction of some automatic types of fire detectors. The combustion products are different for different types of fires, by theirs intensity, size and development time. That is the reason why different types of fire detectors won't react on all types of fires. The fire detector selection presents very important task based on fire characteristics that could be appeared. For reason to affirm the detectors appropriation of usage, all of possible fires were assorted in nine classes, according to the European regulative. The fires were marked from TF1 to TF9.

- TF1 - Open cellulose fire (wood),

- $\mathrm{TF} 2$ - Rapid smoldering pyrolysis fire (wood),

- TF3 - Glowing smoldering fire (cotton),

- TF4 - Open plastic fire (polyurethane),

- TF5 - Liquid fire (n-heptane),

- TF6 - Liquid fire (methylated spirits),

- TF7- Slow smoldering (pyrolysis) wood fire,

- TF8 - Low temperature black smoke (decalene) liquid fire,

- TF9 - Deep seated smoldering cotton fire.

The test fires described by standards present the most fires that could be appeared in real life. The results achieved by these test fires should be used for response time of fire detectors. The base characteristics of test fires are presented in table 1. The classification of international standard ISO 7240-9, which defines the nine classes of fire, with exception of TF7 and TF9, is identical as EN 54-9 standard.

Table 1. Base characteristics of test fires TF1-TF9

\begin{tabular}{||c|c|c|c|c|c|c||}
\hline \hline type & $\begin{array}{c}\text { heat de- } \\
\text { velopment }\end{array}$ & $\begin{array}{c}\text { input } \\
\text { current }\end{array}$ & smoke & $\begin{array}{c}\text { aerosol } \\
\text { specter }\end{array}$ & $\begin{array}{c}\text { visible } \\
\text { part }\end{array}$ & $\begin{array}{c}\text { CO } \\
\text { presence }\end{array}$ \\
\hline TF1 & strong & strong & yes & $\begin{array}{c}\text { mostly } \\
\text { visible }\end{array}$ & dark & ----- \\
\hline TF2 & negligible & week & yes & $\begin{array}{c}\text { mostly } \\
\text { visible }\end{array}$ & bright & yes \\
\hline TF3 & negligible & $\begin{array}{c}\text { very } \\
\text { week }\end{array}$ & yes & $\begin{array}{c}\text { mostly } \\
\text { visible }\end{array}$ & bright & $\begin{array}{c}\text { very } \\
\text { much }\end{array}$ \\
\hline TF4 & strong & strong & yes & $\begin{array}{c}\text { partly in- } \\
\text { visible }\end{array}$ & $\begin{array}{c}\text { very } \\
\text { dark }\end{array}$ & little \\
\hline
\end{tabular}




\begin{tabular}{||c|c|c|c|c|c|c||}
\hline \hline TF5 & strong & strong & yes & $\begin{array}{c}\text { mostly in- } \\
\text { visible }\end{array}$ & $\begin{array}{c}\text { very } \\
\text { dark }\end{array}$ & little \\
\hline TF6 & strong & strong & no & no & no & ----- \\
\hline TF7 & negligible & week & yes & $\begin{array}{c}\text { mostly } \\
\text { visible }\end{array}$ & bright & ---- \\
\hline TF8 & negligible & week & yes & $\begin{array}{c}\text { mostly } \\
\text { visible }\end{array}$ & dark & very little \\
\hline TF9 & week & week & yes & $\begin{array}{c}\text { mostly } \\
\text { visible }\end{array}$ & bright & yes \\
\hline
\end{tabular}

Different parameters of fire detectors related to the proper definite type and quantity of fire material are tested in laboratories, according to the characteristics of the presented test fires. The most important parameter of every fire detector is the response speed. According to this factor, the tables of usage conveniences for some detectors for particular appliances are formatted. For example, the table 2 comprehends data of time and sequence of response for some fire detectors related to the fire types that could be appeared in real life.

Table 2. The sequence of response for some fire detectors related to some fire types

\begin{tabular}{|c|c|c|c|c|c|c|c|c|}
\hline & \multicolumn{8}{|c|}{ Fire detectors type } \\
\hline \multirow[t]{2}{*}{ type } & \multicolumn{2}{|c|}{ Ionizations } & \multicolumn{2}{|c|}{ Optical } & \multicolumn{2}{|c|}{$\begin{array}{c}\text { Thermo differ- } \\
\text { ential }\end{array}$} & \multicolumn{2}{|c|}{$\begin{array}{l}\text { Flame detec- } \\
\text { tors }\end{array}$} \\
\hline & $\begin{array}{c}\text { se- } \\
\text { quence }\end{array}$ & time & $\begin{array}{c}\text { se- } \\
\text { quence }\end{array}$ & time & $\begin{array}{c}\text { se- } \\
\text { quence }\end{array}$ & time & $\begin{array}{c}\text { se- } \\
\text { quence }\end{array}$ & time \\
\hline TF1 & 2. & $\begin{array}{c}190 \\
\mathrm{~S} \\
\end{array}$ & 4. & $\begin{array}{c}<430 \\
\mathrm{~s}\end{array}$ & 3. & $\begin{array}{c}<370 \\
\mathrm{~S}\end{array}$ & 1. & $100 \mathrm{~s}$ \\
\hline TF2 & 2. & $\begin{array}{c}450 \\
\mathrm{~s} \\
\end{array}$ & 1. & $380 \mathrm{~s}$ & - & - & 3. & $\begin{array}{c}<570 \\
\mathrm{~s} \\
\end{array}$ \\
\hline TF3 & 1. & $\begin{array}{c}190 \\
\mathrm{~S}\end{array}$ & 2. & $210 \mathrm{~s}$ & - & - & - & - \\
\hline TF4 & 2. & $\begin{array}{c}<80 \\
\mathrm{~S}\end{array}$ & 3. & $120 \mathrm{~s}$ & 4. & $\begin{array}{c}<220 \\
\mathrm{~S}\end{array}$ & 1. & $<10 \mathrm{~s}$ \\
\hline TF5 & 2. & $\begin{array}{c}<20 \\
\mathrm{~S}\end{array}$ & 4. & $\begin{array}{c}<180 \\
\mathrm{~S}\end{array}$ & 3. & $<95 \mathrm{~s}$ & 1. & $<5 \mathrm{~s}$ \\
\hline
\end{tabular}

Many different factors should be considered for concrete fire detectors selection. This factors issue from expected fire development at early 
stage, objects geometry, ambient characteristics and eventual obstruct factors. Some of these criteria are presented in table 3 (Blagojević, 2011:163).

Table 3. Criteria that influences on fire detectors selection

\begin{tabular}{|c|c|}
\hline Criteria & Possible cases \\
\hline Possible fire type & $\begin{array}{l}\text { - smoldering fire with smoke devel- } \\
\text { opment, } \\
\text { - open fire without smoke develop- } \\
\text { ment, } \\
\text { - open fire with particles. }\end{array}$ \\
\hline Height of the room & $\begin{array}{l}\text { - limitations for fire and smoke de- } \\
\text { tectors }\end{array}$ \\
\hline Ambient conditions & $\begin{array}{l}\text { - temperature, } \\
\text { - humidity, } \\
\text { - air flow... }\end{array}$ \\
\hline Obstruct factors & $\begin{array}{l}\text { - smoke, } \\
\text { - dust, } \\
\text { - electromagnetic radiations... }\end{array}$ \\
\hline
\end{tabular}

Noted facts showing that there are a lot of different factors that should be considered for proper selection of fire detector, so, it is obviously how the complex and hard task that presents. But, that is right way to increase the reliability of the complete system and to decrease the appearance of the possible false alarms. If at least one parameter of fire detectors does not fit to the usage conditions (for example, humidity, surrounding temperature, vibrations, presence of different fumes and similar), fire detector doesn't provide secure work of fire protection system. As an example, the usage convenience of some fire detectors types according to the room height in object are presented in table 4 (Jevtić, Blagojević, 2014), (ISO 7240, 2005), (ISO 7240, 2003), (ISO 7240, 2006).

\section{THE FIRE DETECTOR DISPOSITION IN OBJECT}

There are several standards that deal with this problem: BS (British Standard), NFPA (National Fire Protection Association), НПБ 88-2001 (Нормы пожарной безопасности) and other (Blagojević, 2011:190).

The general rule for needed number of fire detectors and its positioning is to divide the supervised area with detector supervised area. There are lots of other factors that should be considered, such as shape and slope of the roof, barriers, girt, walls positioning, installation positioning, wholes into the 
walls positions, room height etc. The position of the detectors should be easy accessible, because of its testing and repairing. The reduction of the range between detectors leads that the system sensibility becomes higher. It is important to note that increment of fire detector numbers over the optimal limit brings small gain according to the price of the system. Because of that, it is important to find an optimal relation between performance increment and price needed for that. The base scheme of the detector supervised area which is presented on figure 3 could be increase or decrease, in dependence of roof height, its scarp or similar. According to the defined supervised areas, dimensions $s$ and $d^{\prime}$ could be calculated.

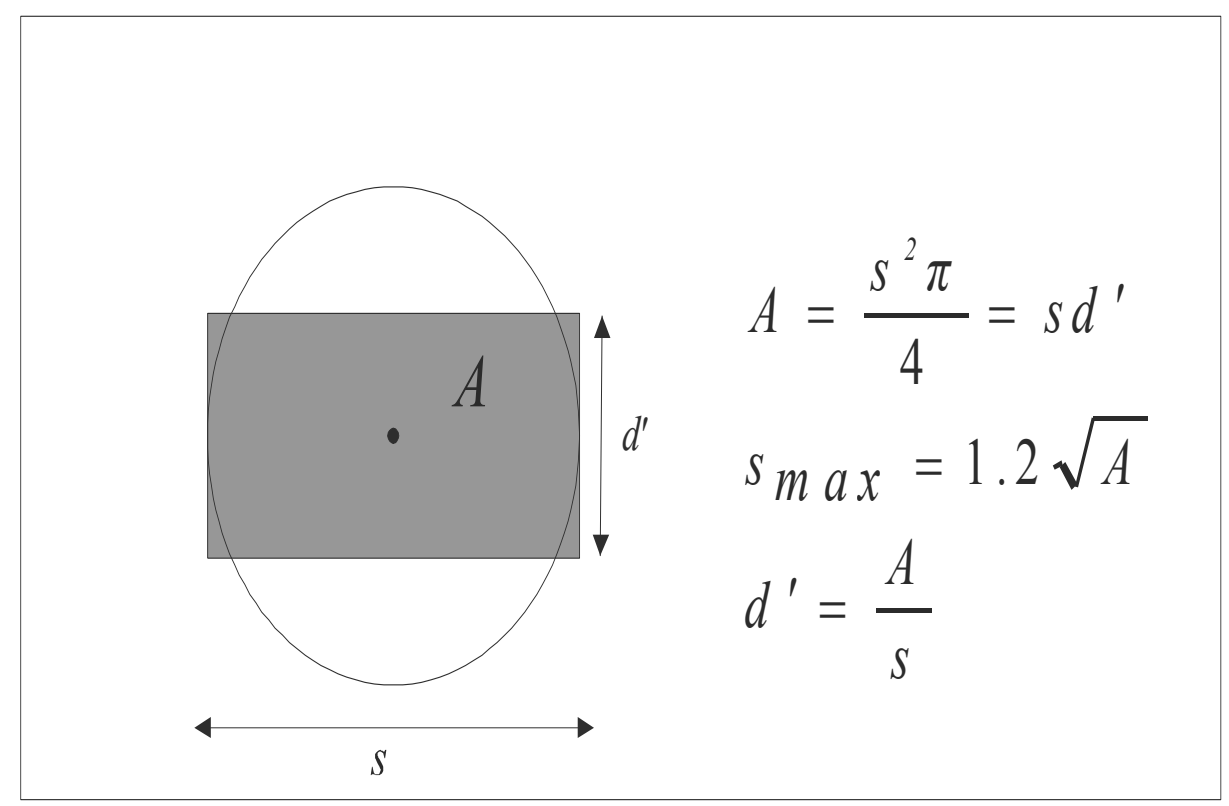

Figure 3. Supervised area of the point fire detector (Source: Blagojević, 2011)

For example, for heat detectors with supervised area $A=30 \mathrm{~m}^{2}$, maximal distance between detectors should be:

$$
S_{\max }=1.2 \sqrt{30}=6.6 \approx 7 \mathrm{~m} .
$$

For the smoke detector with supervised area $\mathrm{A}=80 \mathrm{~m}^{2}$, maximal distance between detectors should be:

$$
s_{\max }=1.2 \sqrt{80}=10.7 \approx 11 \mathrm{~m} .
$$


For flame detectors, the most important factor is supervised volume, so it implies that they are proper in big and height workshops. The angle between possible fire place and optical flame axis should be as bigger as possible.

In some western standards, the supervised detectors area and theirs between distances were slightly different defined in regard on our country. For example, the British standard classifies the covered detector area in two categories according to the rooms' width with plane roof - for rooms with width up to $5 \mathrm{~m}$ and rooms with width higher than $5 \mathrm{~m}$ (BS 5839-6, 2004).

For heat detectors:

1. Rooms with plane roof - wider then $5 \mathrm{~m}$,

- Maximal covered area $50 \mathrm{~m}^{2}$,

- Covering radius $5.3 \mathrm{~m}$, or, for square area with distance from wall from $3.5 \mathrm{~m}$ and distance between detectors from $7 \mathrm{~m}$.

2. Rooms with plane roof - narrower then $5 \mathrm{~m}$ (hall with width $w$ ),

- Covering radius is $(5 \mathrm{~m}-w[\mathrm{~m}]) / 2+5.3 \mathrm{~m}$.

For smoke detectors:

2. Rooms with plane roof - wider then $5 \mathrm{~m}$,

- Maximal covered area $100 \mathrm{~m}^{2}$,

- Covering radius $7.5 \mathrm{~m}$, or, for square area with distance from wall from $5 \mathrm{~m}$ and distance between detectors from $10 \mathrm{~m}$.

2. Rooms with plane roof - narrower then $5 \mathrm{~m}$ (hall with width $w$ ),

- Covering radius is $(5 \mathrm{~m}-w[\mathrm{~m}]) / 2+7.5 \mathrm{~m}$.

This standard also has its own values for according to the room height (BS 5445-5 for heat detectors, BS 5445-7 for smoke detectors, BS 5445-8 for fixed temperature detectors, BS 5839-1 for optical detectors).

American standard NFPA 72 is one of the most detailed and the largest standards that regulate fire detection. For example, the distance between detectors $S$ is formed by references presented on figure 4 . 


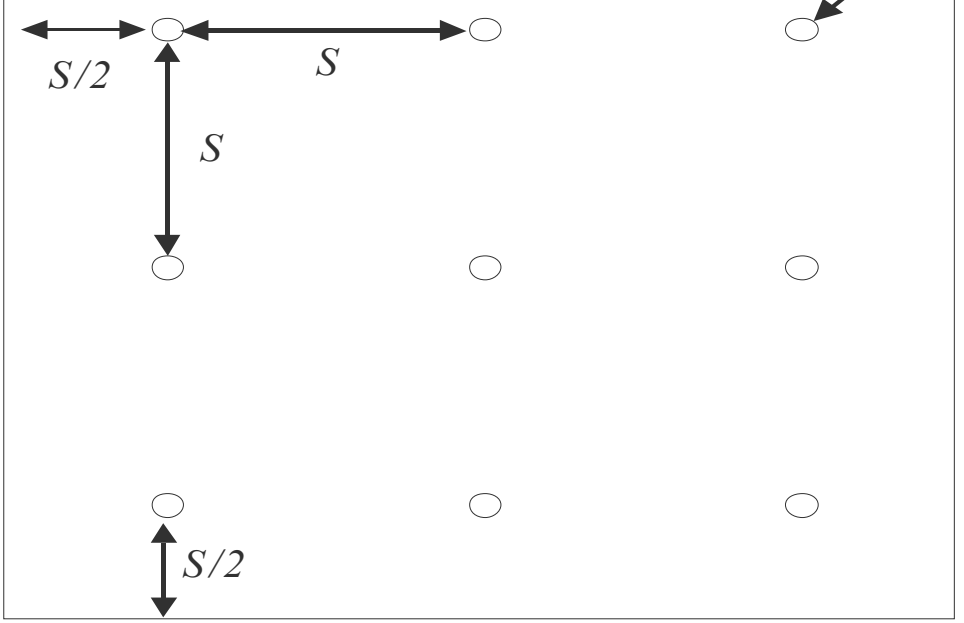

Figure 4. The references for detectors arrangement according to NFPA 72

This standard also has its own regulates for fire detectors arrangement according to room height, no square form of object etc.

The Russian standard NPB 88-2001 (Нормы пожарной безопасност НПБ 88-2001) also has its own regulates. For example, the arrangement of heat and smoke detectors in object are presented in table 4 and 5.

Table 4. Rules for point heat detectors positioning

\begin{tabular}{|c|c|c|c|}
\hline \multirow{2}{*}{$\begin{array}{c}\text { Room height } \\
{[\mathrm{m}]}\end{array}$} & \multirow{2}{*}{$\begin{array}{l}\text { Detector super- } \\
\text { vised area }\left[\mathrm{m}^{2}\right]\end{array}$} & \multicolumn{2}{|c|}{ Maximal range $[\mathrm{m}]$} \\
\hline & & $\begin{array}{c}\text { between detec- } \\
\text { tors }\end{array}$ & $\begin{array}{c}\text { detector from } \\
\text { wall }\end{array}$ \\
\hline up to 3.5 & up to 25 & 5.0 & 2.5 \\
\hline $3.5-6.0$ & up to 20 & 4.5 & 2.0 \\
\hline $6.0-9.0$ & up to 15 & 4.0 & 2.0 \\
\hline
\end{tabular}

Table 5. Rules for point smoke detectors positioning 


\begin{tabular}{|c|c|c|c|}
\hline \multirow{2}{*}{$\begin{array}{c}\text { Room height } \\
{[\mathrm{m}]}\end{array}$} & \multirow{2}{*}{$\begin{array}{c}\text { Detector super- } \\
\text { vised area }\left[\mathrm{m}^{2}\right]\end{array}$} & $\begin{array}{c}|c| \\
\text { between detec- } \\
\text { tors }\end{array}$ & $\begin{array}{c}\text { detector from } \\
\text { wall }\end{array}$ \\
\hline \hline up to 3.5 & up to 85 & 9.0 & 4.5 \\
\hline $3.5-6.0$ & up to 70 & 8.5 & 4.0 \\
\hline $6.0-10.0$ & up to 65 & 8.0 & 4.0 \\
\hline $10.5-12.0$ & up to 55 & 7.5 & 3.5 \\
\hline
\end{tabular}

The same standard has regulates for arrangement of line smoke detectors on height up to $12 \mathrm{~m}$. This regulates are presented in table 6 .

Table 6. Rules for line smoke detectors positioning (up to height of $12 \mathrm{~m}$ )

\begin{tabular}{|c|c|c|}
\hline $\begin{array}{c}\text { Detector height } \\
{[\mathrm{m}]}\end{array}$ & $\begin{array}{c}\text { Maximal range between } \\
\text { optical axes of detectors } \\
{[\mathrm{m}]}\end{array}$ & $\begin{array}{c}\text { Maximal range of optical axe } \\
\text { of detector from the wall [m] }\end{array}$ \\
\hline \hline up to 3.5 & 9.0 & 4.5 \\
\hline $3.5-6.0$ & 8.5 & 4.0 \\
\hline $6.0-10.0$ & 8.0 & 4.0 \\
\hline $10.0-12.0$ & 7.5 & 3.5 \\
\hline
\end{tabular}

An example for choice of fire detectors related to the room height according to German DIN VDE 0833-2-2009 is presented in table 7.

Table 7. The usage convenience of fire detectors types related to the room height according to the DIN VDE 0833-2 


\begin{tabular}{|c|c|c|c|c|c|c|}
\hline $\begin{array}{l}\text { Room } \\
\text { height }\end{array}$ & $\begin{array}{l}\text { Point } \\
\text { smoke } \\
\text { detec- } \\
\text { tors } \\
\text { DIN } \\
\text { EN } \\
\mathbf{5 4 - 7}\end{array}$ & $\begin{array}{l}\text { Line } \\
\text { smoke } \\
\text { detect } \\
\text { ors } \\
\text { DIN } \\
\text { EN } \\
\mathbf{5 4 - 1 2}\end{array}$ & $\begin{array}{c}\text { Aspira- } \\
\text { tion } \\
\text { smoke } \\
\text { detec- } \\
\text { tors } \\
\text { DIN } \\
\text { EN } \\
\mathbf{5 4 - 2 0} \\
\text { class A, } \\
\text { B and C }\end{array}$ & $\begin{array}{c}\text { Point heat } \\
\text { detectors } \\
\text { DIN EN } \\
\mathbf{5 4 - 5} \\
\text { class A1, } \\
\text { A2, B, C, } \\
\text { D, E, F } \\
\text { and G, a, } \\
\text { b }\end{array}$ & $\begin{array}{c}\text { Line } \\
\text { heat } \\
\text { detector } \\
\text { DIN EN } \\
\text { 54- } \\
\mathbf{2 2} \\
\text { class A1 } \\
\text { and } \\
\text { A2 }\end{array}$ & $\begin{array}{c}\text { Point } \\
\text { flame } \\
\text { detector } \\
\text { DIN EN } \\
\mathbf{5 4 - 1 0} \\
\text { class 1, } \\
2 \text { and } 3\end{array}$ \\
\hline $\begin{array}{l}\operatorname{up}_{4} \text { to } \\
45 \mathrm{~m}\end{array}$ & & & & & & c \\
\hline $\begin{array}{l}\text { up to } \\
20 \mathrm{~m}\end{array}$ & & $\mathrm{~d}$ & $\begin{array}{c}\text { class A, } \\
\mathrm{d}\end{array}$ & & & $\mathrm{c}$ \\
\hline $\begin{array}{l}\text { up to } \\
16 \mathrm{~m}\end{array}$ & & & $\begin{array}{c}\text { class A } \\
\text { and B }\end{array}$ & & & c \\
\hline up $_{\text {to } 12 \mathrm{~m}}$ & & & & & & \\
\hline $\begin{array}{l}\text { up to } 9 \\
\text { m }\end{array}$ & & & & & class A1 & \\
\hline $\begin{array}{l}\text { up to } \\
7,5 \mathrm{~m}\end{array}$ & & & & class A1 & & \\
\hline up to 6 & & & & & & \\
\hline & \multicolumn{6}{|c|}{ inopportune } \\
\hline & \multicolumn{6}{|c|}{ proper according to the ambient conditions and busyness } \\
\hline & \multicolumn{6}{|l|}{ proper } \\
\hline a & \multicolumn{6}{|c|}{ also detectors with $\mathrm{R}$ and $\mathrm{S}$ marks } \\
\hline $\mathrm{b}$ & \multicolumn{6}{|c|}{ classes B, C, D, F and G appropriate for local usage } \\
\hline $\mathrm{c}$ & \multicolumn{6}{|c|}{ dependence on class or configuration } \\
\hline $\mathrm{d}$ & \multicolumn{6}{|c|}{ allowed with proved efficiency } \\
\hline
\end{tabular}

Although the noted standards provide detail and analytic approach to fire problematic, there are possible deviation related to some tasks, but that demands of many different factors and special cases. The noted facts above were only the base and general rules for detectors arrangement in object. The limits of this paper do not allow the presentation of every rule and regulative for detectors disposition in object, but also this is enough for understanding of how this problem might be complicate and demanding (Blagojević, 2011:171), (U. S. Department of Energy, 1999), (Živković, Babić, 2010), (Babić, Mlađan, 2013). 


\section{SIMULATION AND SIMULATION RESULTS}

Simulation of fire in object with heat and smoke fire detectors was realized in PyroSim software. The dimensions of the object were $30 \times 20 \times 3$, $2 \mathrm{~m}$, and the object had a rectangle form with horizontal roof. The area of the object was $600 \mathrm{~m}^{2}$. Heat and smoke detectors were positioned according to the NFPA standard (NFPA 72, 1999). It is important to note that the references of different standards are similar but not identycal (НПБ 88-2001, 2001). The complete number of heat detectors was 20 and the complete number of smoke detectors was 8 . Heat detectors used in simulation were set to activate on temperature of $75^{\circ} \mathrm{C}$. The response time index (RTI) was set to $100 \mathrm{~m}^{1 / 2} \mathrm{~s}^{1 / 2}$. Some other standards, such as, for example, EN 54, regulates reaction temperature for alarm of $57^{\circ} \mathrm{C}$, but, in order to avoid false alarms, in practice, reaction temperature is relatively high (more than $70^{\circ} \mathrm{C}$ ). There are a lot of different ways for construction and realization of heat detectors (Stanković , 1997:312), (Jevtić, Blagojević, 2013).

Smoke detectors were set to activate at 3,25\% of obscuration. The heat detectors were presented with red color while the smoke detectors were presented with green color on simulation model. The fire source was presented as burner, size $2 \times 2 \mathrm{~m}$. The heat release rate per area (HRR) of fire source was set to 100,200 and $500 \mathrm{~kW} / \mathrm{m}^{2}$. The duration of the complete simulation was 200 seconds, for every of three cases. The PyroSim 2012 simulation model with fire source and detectors positions in the object is presented on figure 5, while the fire propagation in simulated object with its thermal presentation is presented on figure 6 . The reason for chosen fire sources was in fact that fire detectors should detect fire at early stage (for example, slow fire with solid wood cabinets has HRR less than $500 \mathrm{~kW}$ in 300 seconds, while medium fire has more than HRR greater than 1MW). The reason for the chosen dimension of object was in fact that there were many magazines, storehouses with similar or identical dimensions (Thunderhead, 2012).

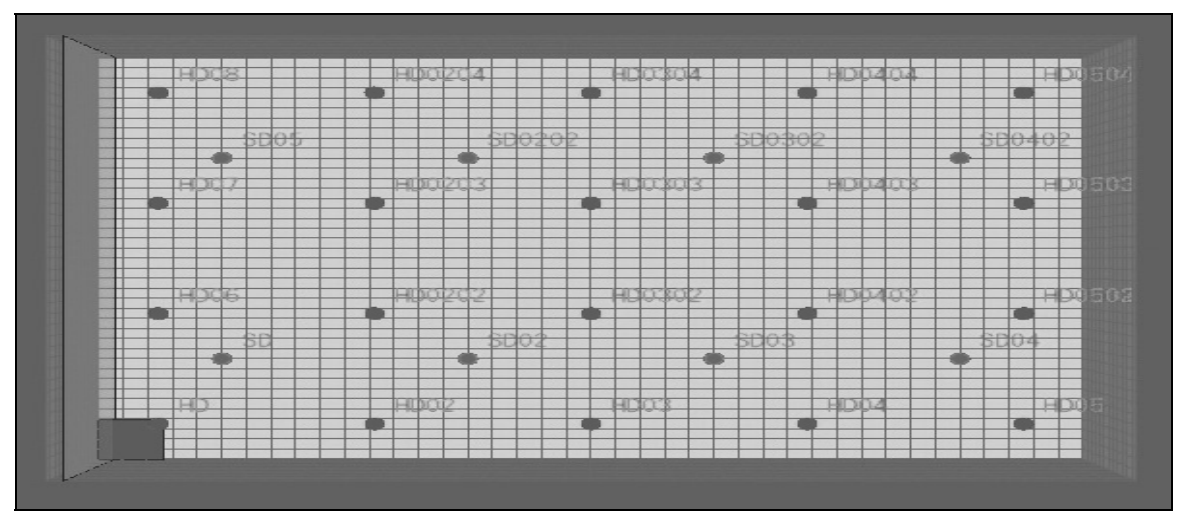


Figure 5. Simulation model in PyroSim with heat and smoke detectors disposition

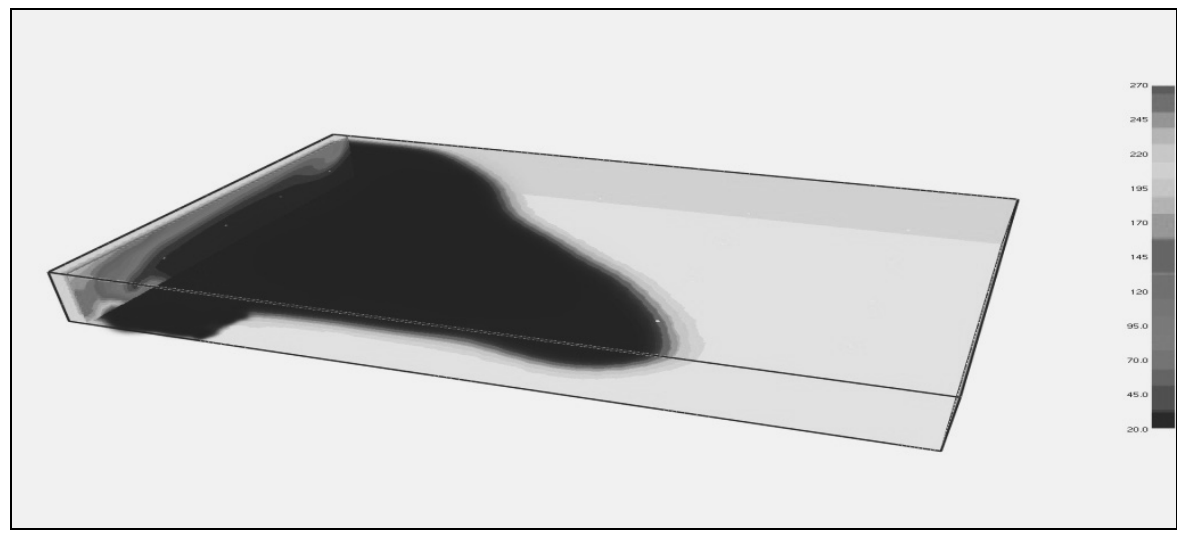

Figure 6. Fire propagation with thermal presentation in simulated object after 20 seconds

Some of simulation results which present response for the closer and further smoke and heat detectors for HRR of 100,200 and $500 \mathrm{~kW} / \mathrm{m}^{2}$ are presented from figure 7 to figure 12 .

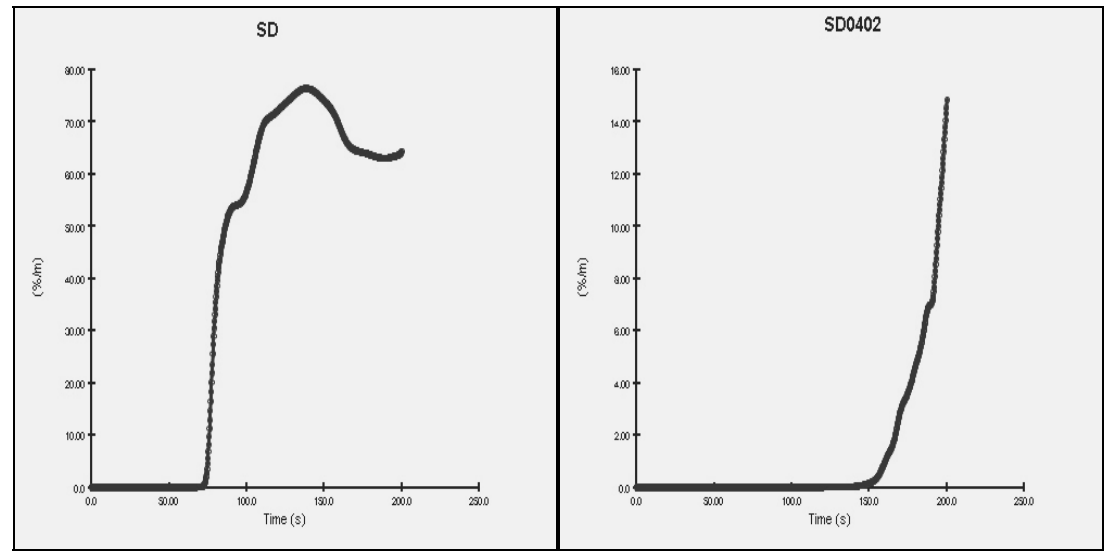

Figure 7. The responses for the closer and farther smoke detector from fire source for HRR of $100 \mathrm{~kW} / \mathrm{m}^{2}$ 


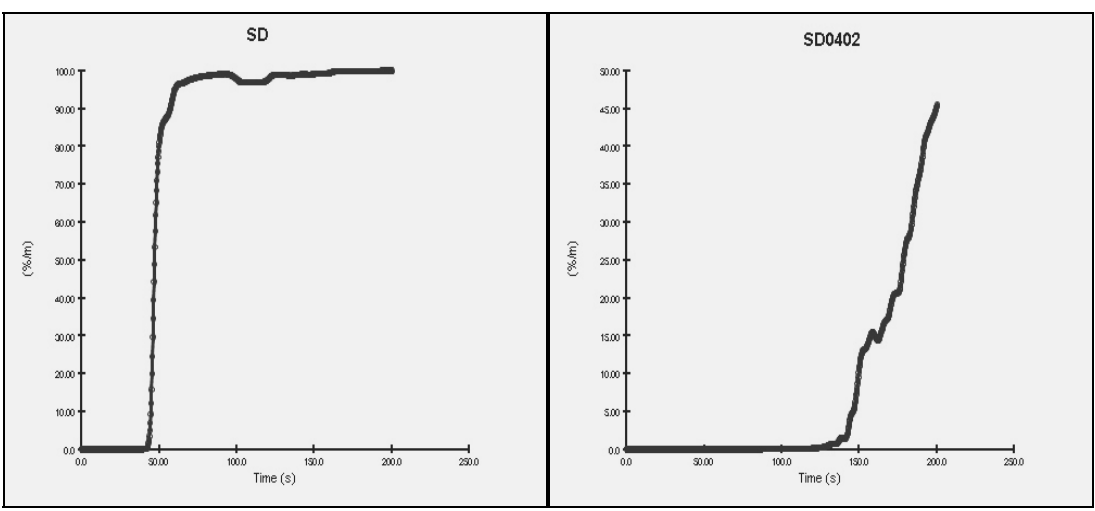

Figure 8. The responses for the closer and farther smoke detector from fire source for HRR of $200 \mathrm{~kW} / \mathrm{m}^{2}$

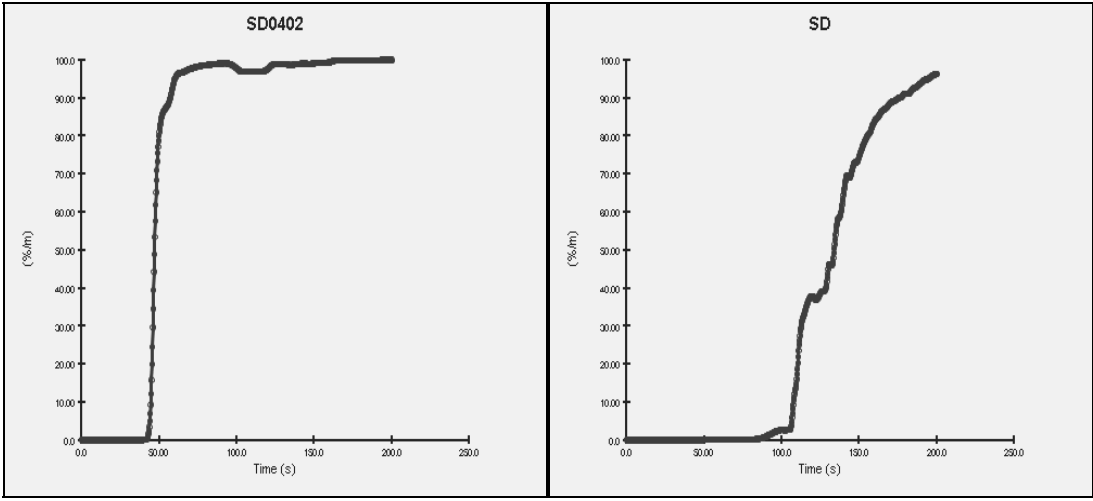

Figure 9. The responses for the closer and farther smoke detector from fire source for HRR of $500 \mathrm{~kW} / \mathrm{m}^{2}$

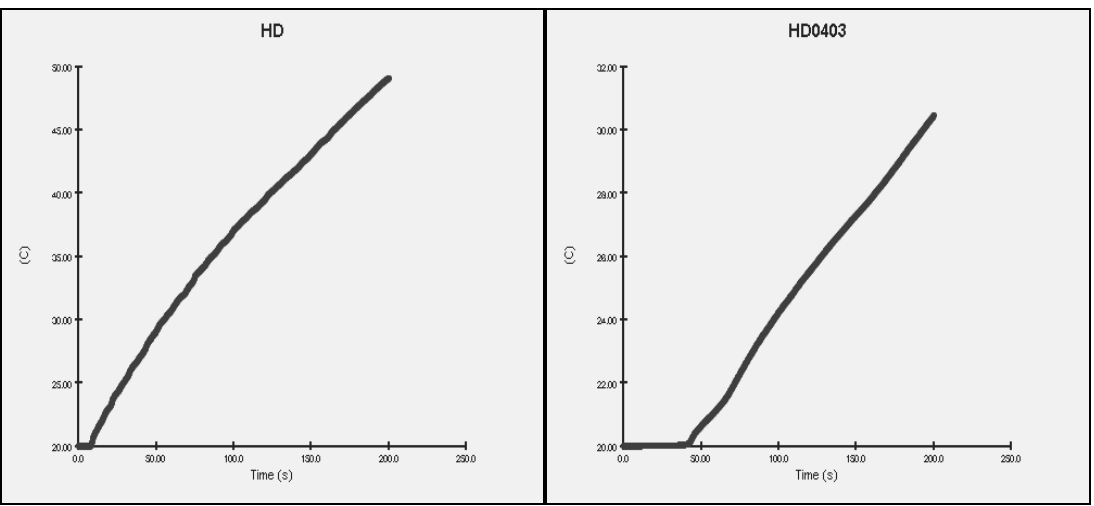

Figure 10. The responses for the closer and farther heat detector from fire source for HRR of $100 \mathrm{~kW} / \mathrm{m}^{2}$ 


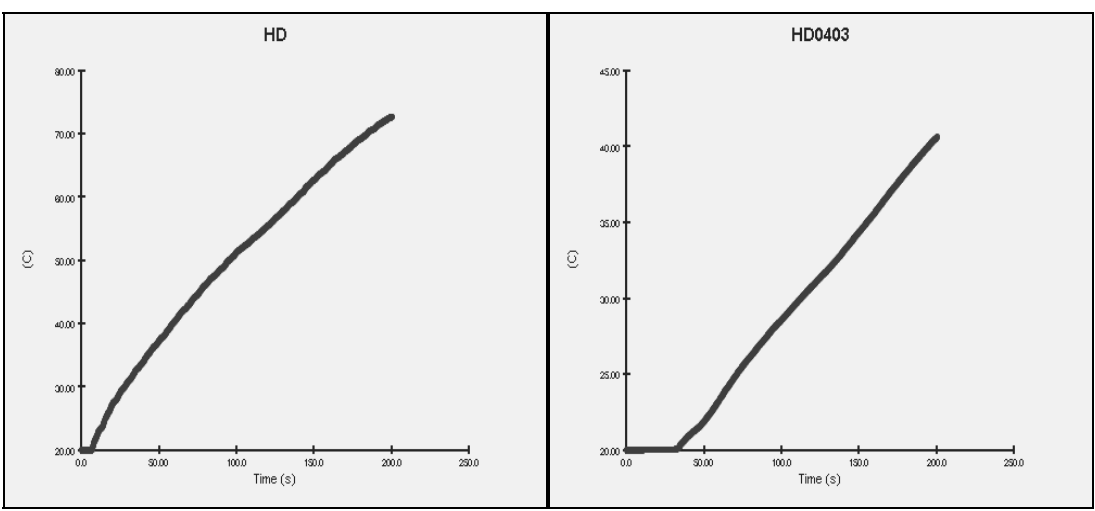

Figure 11. The responses for the closer and farther heat detector from fire source for HRR of $200 \mathrm{~kW} / \mathrm{m}^{2}$

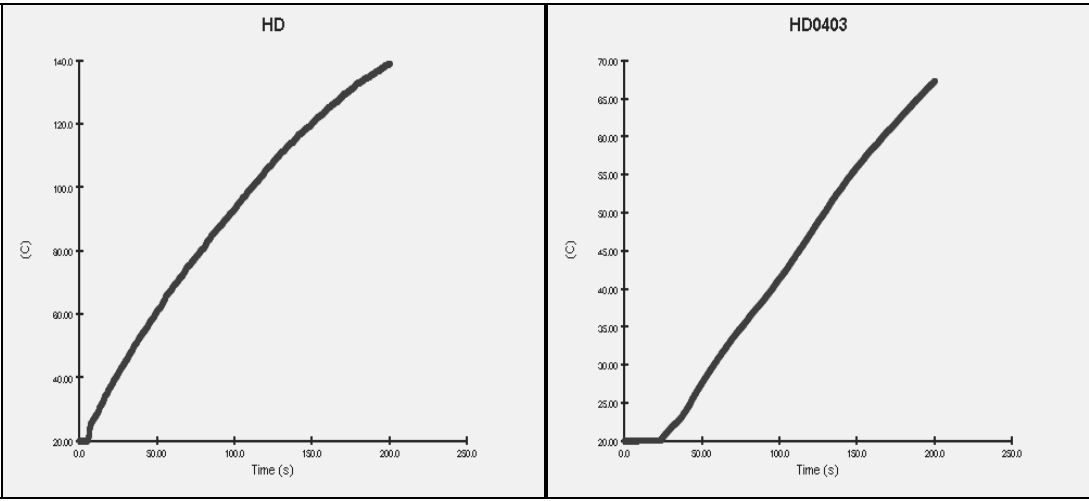

Figure 12. The responses for the closer and farther heat detector from fire source for HRR of $500 \mathrm{~kW} / \mathrm{m}^{2}$

\section{DISCUSSION}

The complete simulation results, which present the reaction times of the first detectors and reaction times of the all smoke detectors, are presented on figure 13. The simulation results showed that, for the complete simulation time from 200 seconds, every of smoke detectors would react. In case of heat detectors, simulation results showed that, in the firs case where the HRR was $100 \mathrm{~kW} / \mathrm{m}^{2}$, none of heat detectors would react for simulation time of 200 seconds. In the second case, where the HRR was $200 \mathrm{~kW} / \mathrm{m}^{2}$, only three heat detectors would react, and in the last case, where the HRR was $500 \mathrm{~kW} / \mathrm{m}^{2}$, fourteen heat detectors would react. The responses for heat detectors and the 
number of activated heat detectors for different HRR of 100, 200 and 500 $\mathrm{kW} / \mathrm{m}^{2}$ are presented on figure 14 .

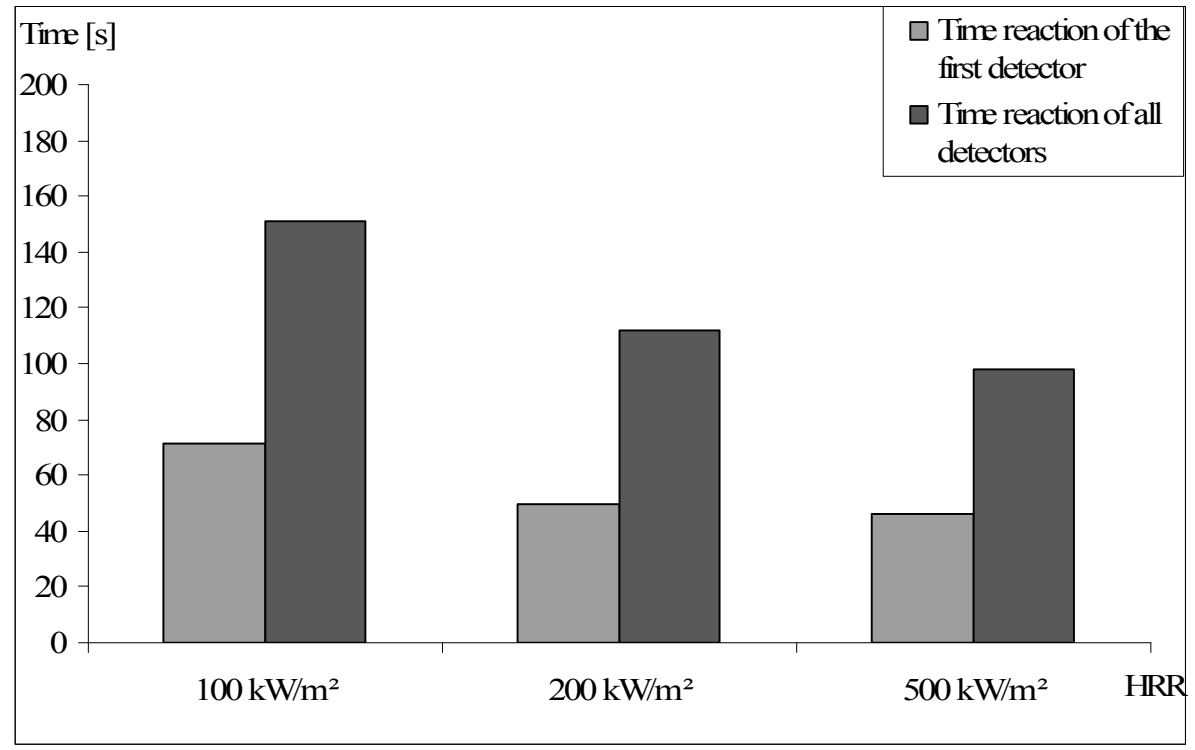

Figure 13. The responses for smoke detectors for different HRR of 100, 200 and $500 \mathrm{~kW} / \mathrm{m}^{2}$

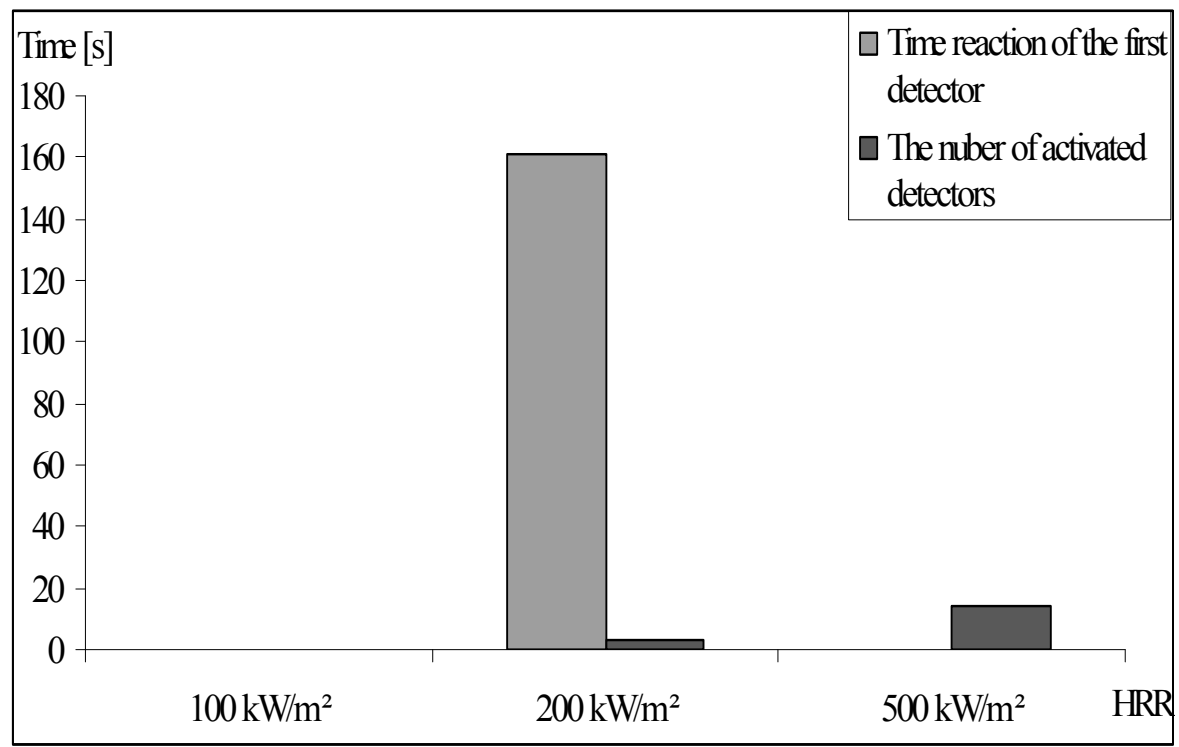

Figure 14. The responses for heat detectors and the number of activated heat detectors for different HRR of 100, 200 and $500 \mathrm{kW/m}{ }^{2}$ 


\section{CONCLUSION}

The simulation results for combinational disposition of smoke and heat detectors showed how the complicated problem of detector selection could be. Simulation model was a simple empty object without any special demands. Even in that case, alarm reactions wouldn't be realized with only heat detectors, in the first case. That means that only with the usage of heat detectors, object protection was poor, for HRR of $100 \mathrm{~kW} / \mathrm{m}^{2}$. In all of three cases, smoke detectors have reacted. More complicate objects with more demands would require bigger number of different types of detectors, possible their thicker disposition based on some of noted standards or even with some excursions. It implies the usage of many noted regulative and roles. Also, it was obvious that fire source with bigger HRR implied faster detection and activation more detectors in object.

Generally, this and similar simulation results showed that every object should have a unique approach of fire protection, respecting all of possible demands, roles, regulative and conditions. The detectors selection with their disposition always must provide right time reaction and fire detection with acceptable price. The next steps of researching would be in arrangement of fire detectors according to some typical (triangle, hexagonal) or no typical way in no square objects with special content inside (for example, objects with different kind of roof with curvatures in theirs form). These and similar results have great value not only in fire prediction, propagation and elimination (Jevtić, 2014a), (Jevtić, Ničković, 2014), (Davidović and associates, 2013), (Živanović, 2012) but also in prediction and realization of possible evacuation routes for humans to leave the object safely (Thunderhead, 2012).

\section{REFERENCES:}

1. Babić, Đ. and Mlađan, D., (2013). Analiza pokazatelja rizika od požara i eksplozija s posebnim osvrtom na Republiku Srbiju, Bezbednost, Vol. 3, pp. 117-129.

2. Blagojević, Đ. M., (2011). Alarm systems, Faculty of occupational safety in Niš, ISBN 978-86-6093-025-7, Niš, pp. 37-40, 163-168, 171$175,190-195$.

3. BS 5839-6, (2004): Fire Detection and Alarm Systems for Buildings. Code of Practice for the Design and Installation of Fire Detection and Alarm Systems in Dwellings.

4. Davidović, M., Hadžiefendić, N. and Trifunović, J., (2013). Opasnost od požara usled korišćenja elektroinstalacionih komponenti lošeg kvaliteta-produžni kablovi, Bezbednost, Vol. 1, pp. 140-160.

5. DIN VDE 0833-2 (VDE 0833-2), (2009). 
6. Furness A., Mucket M., (2007). Introduction to Fire Safety Management, Elsevier, ISBN 978-0-7506-8068-4.

7. ISO 7240, (2003). Fire detection and alarm systems - Part 14: Guidelines for drafting codes of practice for design, installation and use of fire detection and fire alarm systems in and around building.

8. ISO 7240, (2005). Fire Detection and Alarm systems - Part 1: General and Definitions.

9. ISO 7240, (2006) Fire detection and alarm systems -- Part 9: Test fires for fire detectors.

10. Jevtić, B. R, (2014). The importance of fire simulation in fire prediction, Tehnika, Vol 1., ISSN 0040-2176, Belgrade, pp. 153-158.

11. Jevtić, B. R, Blagojević, Đ. M., (2014). On a linear fire detection using coaxial cables, Thermal Science, Vol. 18, No. 2, pp. 603-614.

12. Jevtić, B. R, Blagojević, Đ. M.,(2013). Simulation of the school object evacuation, Tehnika elektrotehnika, Vol 2, Belgrade, pp. 365-370.

13. Jevtić, B. R., (2014). The fire and burglary protection using by no typical electrical lines, $\mathrm{PhD}$ thesis, University of Niš, Niš.

14. Jevtić, B. R., Ničković, T. J., (2014). The determination of fire propagation by simulation, $58^{\text {th }}$ ETRAN CONFERENCE, Vmjačka Banja.

15. National Institute of Standards and Technology, (2010). Fire Dynamic Simulator, Baltimore, Maryland, USA.

16. NFPA 72, (1999). National Fire Alarm Code, 1999 Edition, NFPA.

17. Stanković D., (1997). Physics technical measurements-Sensors, University in Belgrade, Belgrade, pp. 312-320.

18. Thunderhead, (2012). Pathfinder Exmple Guide, USA.

19. U. S. Department of Energy, (1999). Fire Protection Design Criteria, DOE-STD-1066-99, Washington.

20. Živanović, S., (2010). Faktori rizika šuma od požara, Bezbednost, Vol. 2, pp. 179-190.

21. Živanović, S., (2012). Modeling the direction of the fire spread of forest fire to prediction, NBP- Journal of criminalistics and law, Vol. 2, pp. 163-171.

22. Živković, S. and Babić, Đ., (2010). Analiza stanja zaštite od požara $i$ eksplozija u Republici Srbiji, Bezbednost, Vol. 3, pp. 198-212.

23. НПБ 88-2001, (2001): Нормы пожарной безопасностиУстановки пожаро-тушения и сигнализащии. Нормь и правила проектирования, Министерство Внутренних Российской Федерации. 


\section{Правилан избор детектора пожара и њихов распоред у објекту}

Апстракт: Појава пожара у објектима, посебно у објектима у којима много ьуди представља веома могућу реалну ситуачију која може бити веома опасна и проузроковати деструктивне последице по ьудске животе и материјалну својину. Веома важан задатак у заштити од пожара, људској и материјалној безбедности може бити и правилан избор детектора пожара и нихов распоред у објекту. Правилан тип детектора пожара, са юиховим распоредом и густином у објекту треба да обезбеди правовремену реакиију, са минималном појавом лажних аларма и прихватљиву цену. Са друге стране, постоји неколико стандарда за распоред детектора пожара у објекту. Ове чињенице покаузју да добро пројектовани системи за заштиту од пожара морају задовољити много различитих и важних задатака. Овај рад представља презентачију детектора пожара, юихов избор у зависности од различитих фактора, юихов распоред у објекту у зависности од одговарајућих стандарда и симулачију у програму ПуроСим, као доказу за изнете чињенище.

Кључне речи: пожар, детектор, симулација, објекат 